\title{
Transcription analysis on response of porcine alveolar macrophages to Haemophilus parasuis
}

\author{
Yang Wang ${ }^{1}$, Chong Liu', Ying Fang ${ }^{1}$, Xiaoli Liư ${ }^{3}$, Wentao Li', Shuqing Liu', Yingyu Liu', Yuxi Liu', \\ Catherine Charreyre ${ }^{2}$, Jean-Christophe Audonnet ${ }^{2}$, Pin Chen $^{1}$ and Qigai He ${ }^{1 *}$
}

\begin{abstract}
Background: Haemophilus parasuis (H. parasuis) is the etiological agent of Glässer's disease in pigs. Currently, the molecular basis of this infection is largely unknown. The innate immune response is the first line of defense against the infectious disease. Systematical analysis on host innate immune response to the infection is important for understanding the pathogenesis of the infectious microorganisms.

Results: A total of 428 differentially expressed (DE) genes were identified in the porcine alveolar macrophages (PAMs) 6 days after $H$. parasuis infection. These genes were principally related to inflammatory response, immune response, microtubule polymerization, regulation of transcript and signal transduction. Through the pathway analysis, the significant pathways mainly concerned with cell adhesion molecules, cytokine-cytokine receptor interaction, complement and coagulation cascades, toll-like receptor signaling pathway, MAPK signaling pathway, suggesting that the host took different strategies to activate immune and inflammatory response upon $\mathrm{H}$. parasuis infection. The global interactions network and two subnetworks of the proteins encoded by DE genes were analyzed by using STRING. Further immunostimulation analysis indicated that mRNA levels of S100 calcium-binding protein A4 (S100A4) and S100 calcium-binding protein A6 (S100A6) in porcine PK-15 cells increased within $48 \mathrm{~h}$ and were sustained after administration of lipopolysaccharide (LPS) and Poly (I:C) respectively. The s100a4 and s100a6 genes were found to be up-regulated significantly in lungs, spleen and lymph nodes in H. parasuis infected pigs. We firstly cloned and sequenced the porcine coronin 1 a gene. Phylogenetic analysis showed that poCORONIN $1 \mathrm{~A}$ belonged to the group containing the Bos taurus sequence. Structural analysis indicated that the poCORONIN 1A contained putative domains of Trp-Asp (WD) repeats signature, Trp-Asp (WD) repeats profile and Trp-Asp (WD) repeats circular profile at the $\mathrm{N}$-terminus.
\end{abstract}

Conclusions: Our present study is the first one focusing on the response of porcine alveolar macrophages to $\mathrm{H}$. parasuis. Our data demonstrate a series of genes are activated upon H. parasuis infection. The observed gene expression profile could help screening the potential host agents for reducing the prevalence of $\mathrm{H}$. parasuis and further understanding the molecular pathogenesis associated with $H$. parasuis infection in pigs.

\section{Background}

The pig is an important agricultural animal and is an excellent mammalian model for biomedical research $[1,2] . H$. parasuis is the etiological agent of porcine polyserositis and arthritis (Glässer's disease) characterized by fibrinous polyserositis, meningitis and polyarthritis, causing severe economic losses to the swine industry [3]. To date, 15 serovars of $H$. parasuis have been

\footnotetext{
* Correspondence: heqigai@yahoo.com

${ }^{1}$ State key Laboratory of Agricultural Microbiology, Division of Animal Infectious Disease, Huazhong Agricultural University, Wuhan, Hubei, China Full list of author information is available at the end of the article
}

identified [4]. H. parasuis infection can be acute or chronic, depending on the immunological status of the herd [3]. The infection by $H$. parasuis has become an increasing threat to early-weaned pigs and in pig herds of high health status $[5,6]$.

The innate immune response in vertebrates is the first defense line against invading microorganisms. The main players in innate immunity are phagocytes such as neutrophils, dendritic cells and macrophages [7]. As a major component of the host innate immunity, macrophages have essential roles in host defense to infection, because they often mediate the killing of microbes as well as

\section{Biomed Central}


initiate, maintain and resolve host inflammatory responses by releasing cytokines and chemokines [8-11]. Bacterial pathogens that overcome host defenses ensure their ability to survive and propagate $[10,12]$. The diversity of bacteria and the differences in their pathogenesis may lead to pathogen-specific responses of macrophages [10]. A greater understanding of the complex interactions, which occur between the macrophages and pathogen, could lead to the identification of the host defense strategies and the complementary pathogen evasion strategies $[8,10]$. The interactions between $H$. parasuis with porcine alveolar macrophages have been studied [13], but the detailed mechanisms of how porcine alveolar macrophages response to $H$. parasuis infection are not well elucidated. The high throughput cDNA microarray represents a powerful tool for analyzing the molecular events in bacteria-host cell interactions [14]. This technology has been useful in identifying changes in gene expression both in cultured cells and in whole organisms infected with pathogens $[12,15,16]$. In this study, we applied this high throughput cDNA microarray assay to improve our understanding of the innate immune response of macrophages to $H$. parasuis infection.

\section{Results}

\section{Clinical evaluation of infected pigs}

In the challenge group, at $144 \mathrm{~h}$ post-infection, all three pigs had a rectal temperature of over $40.6^{\circ} \mathrm{C}$ and displayed lateral recumbency or labored breathing. At 144 $\mathrm{h}$ post-infection, all pigs including three control pigs were euthanized by intravenous administration of an overdose of sodium pentobarbital. In the challenge group, severe fibrinous polyserositis, arthritis and meningitis were observed at necropsy. On the other hand, in the control group, three pigs remained clinically normal throughout the experiment and did not have lesions at necropsy. The detection of $H$. parasuis by bacterial isolation, nested PCR and LAMP in different samples are shown in Table 1 . The results indicated that the $H$. parasuis could be detected in the lymph nodes, lungs and spleen in all of the three pigs that challenged with $H$. parasuis serovar 5 SH0165 strain. In contrast, $H$. parasuis could not be detected by the three methods in the control group.

\section{Overview of differential expressed genes in PAMs}

To investigate the dynamic gene transcriptional profiles of PAMs in response to $H$. parasuis infection, six microarrays were used in this experiment, corresponding to the RNAs from PAMs of three $H$. parasuis infected piglets and three controls. The total RNA samples were hybridized with Affymetrix GeneChip Porcine Genome Array, and the microarray data were analyzed using Significance Analysis of Microarrays (SAM) [17].
Table 1 Results of culture, nested PCR and LAMP analysis for three pigs challenged with $\boldsymbol{H}$. parasuis serovar 5 , presented as the number of pigs positive/pigs samples

\begin{tabular}{cccc}
\hline Samples & H. parasuis culture $^{\text {a }}$ & Nested PCR & LAMP \\
\hline Brain & $0 / 3$ & $1 / 3$ & $1 / 3$ \\
Lymph node & $3 / 3$ & $3 / 3$ & $3 / 3$ \\
Tonsil & $2 / 3$ & $2 / 3$ & $2 / 3$ \\
Lung & $3 / 3$ & $3 / 3$ & $3 / 3$ \\
Pericardial fluid & $2 / 3$ & $2 / 3$ & $2 / 3$ \\
Heart & $1 / 3$ & $1 / 3$ & $1 / 3$ \\
Spleen & $3 / 3$ & $3 / 3$ & $3 / 3$ \\
Total site & $14 / 21$ & $15 / 21$ & $15 / 21$ \\
\%positive & 67 & 71 & 71 \\
\hline
\end{tabular}

a: if $H$. parasuis was not identified by culture due to contaminated overgrowth, presence of $H$. parasuis was checked by nested PCR and LAMP on a colony sweep.

Hybridization results indicated that 14,228 and 13,813 probes sets, corresponding to $58.9 \%$ and $57.3 \%$ of all probe sets, were detected in $H$. parasuis serovar 5 and mock-infected PAMs (Additional file 1). After quantile normalization and statistical analysis, 623 transcripts were identified at SAM $|\operatorname{Score}(\mathrm{d})| \geq 2$. Furthermore, Genes whose relative transcription levels showed a fold change FC $\geq 1.33$ and SAM $\mid$ Score $(d) \mid \geq 2$ were considered to be up-regulated, and those with an $\mathrm{FC} \leq 0.75$ and SAM $|\operatorname{Score}(\mathrm{d})| \geq 2$ were considered to be down-regulated. In this study, 575 transcripts showed a level of expression that differed significantly from that of the control group with $H$. parasuis serovar 5 SH0165 strain infected group. These included 428 genes annotated with DAVID or by searching against the GenBank database (Additional file 2). Among these, 338 genes were upregulated and 90 genes were down-regulated (Figure 1). The functions of the DE genes were analyzed by Molecular Annotation System 3.0 software http://www.capitabio.com[18]. In the MAS 3.0 tool, the GO terms and KEGG pathways are ranked with statistical significance by calculating their $p$-values based on hypergeometric distribution [19]. Go terms and KEGG pathways with $p$ values less than 0.05 are considered statistically significant [20]. Among the 428 annotated genes, a total of 229 genes were grouped into 156 categories based on biological process Gene Ontology (GO) terms with the $p$-values less than 0.05 (Additional file 3). Several GO terms were associated with the immune system. These were "inflammatory response" (GO:0006954, $p=2.06 \mathrm{E}-$ 04), "immune response" (GO:0006955, $p=1.75 \mathrm{E}-03)$, "complement activation, classical pathway" (GO:0006958, $p=9.48 \mathrm{E}-04$ ) and "leukocyte migration" (GO:0050900, $p=9.55 \mathrm{E}-03$ ). Particularly, the DE genes associated with immune and inflammatory response suggested that they play roles in host defense response to $H$. parasuis infection (Table 2 ). To gain insight into 


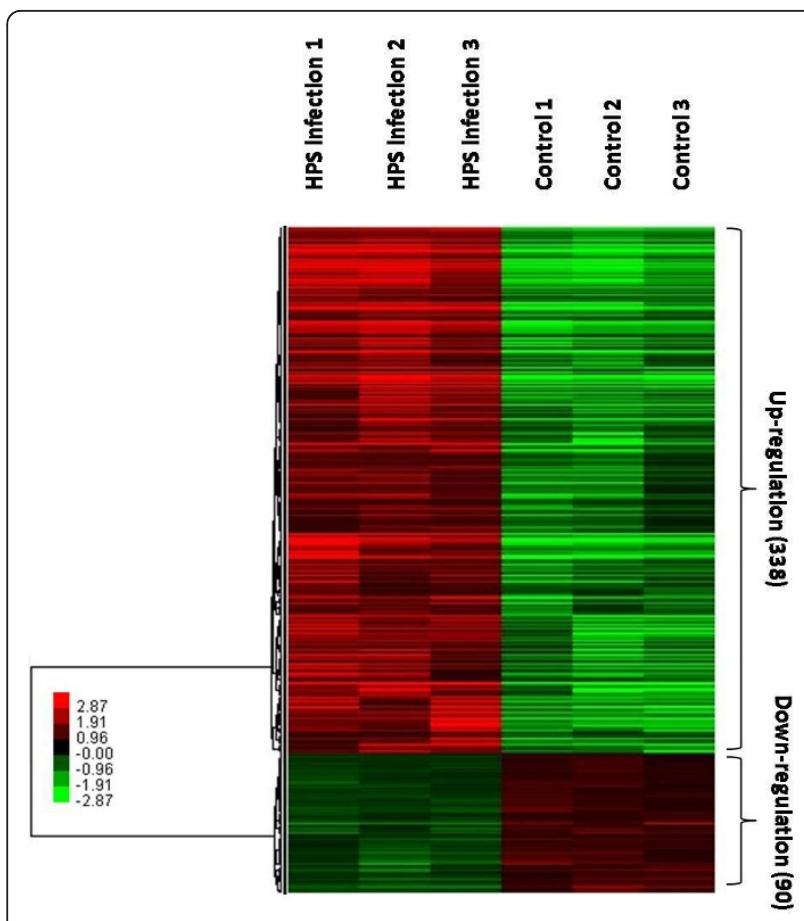

Figure 1 A hierarchical cluster of 428 transcripts following $H$. parasuis infection in PAMs. Each row represents a separate transcript and each column represents a separate piglet. Color legend is on the left, red indicates increased transcript expression levels, whereas green indicates decreased levels compared with normal samples. Up-/down-regulated response transcripts are highlighted on the right with the No. in each cluster in parentheses. Fold change is calculated based on the mean intensity value from 3 donors within each group.

the different biological processes of $H$. parasuis infection, a pathway analysis by KEGG database was performed on DE genes (Additional file 4) [18]. The significant pathways mainly contained: cell adhesion molecules $(p=3.74 \mathrm{E}-12)$, cytokine-cytokine receptor interaction $(p=2.18 \mathrm{E}-10)$, complement and coagulation cascades ( $p=1.16 \mathrm{E}-07)$, toll-like receptor signaling pathway $(p=1.93 \mathrm{E}-05)$, MAPK signaling pathway $(p=$ 7.63E-04), which suggested that the host took different strategies to activate immune and inflammatory response upon $H$. parasuis infection.

\section{Validation of microarray data by quantitative real-time PCR (qPCR)}

In order to confirm the statistical significance of our findings, we performed quantitative real-time PCR (qPCR) analysis of the relevant genes in our original samples used in microarray study. Eleven genes were selected for qPCR analysis. Ten selected genes that were up-regulated in microarray also showed significantly higher expression in $H$. parasuis serovar 5 infected samples than in the control samples determined by qPCR analysis. The ppp1r13l gene that was down-regulated in microarray data also showed significantly lower expression in $H$. parasuis serovar 5 infected samples than in the control samples by qPCR (Table 3 ).

\section{STRING analysis of the relationships between DE genes} STRING is a web-based interface that could predict protein associations which can mean direct physical binding and can also mean indirect interaction such as participation in the same metabolic pathway or cellular process on the basis of genomic context, high-throughput experiments, co-expression and data from the literature http://string.embl.de[21,22]. DE genes were analyzed using STRING for predicting network of proteins encoded by DE genes. Among the 428 annotated DE genes, 236 genes containing 181 up-regulated genes and 55 down-regulated genes were eligible to STRING analyses when the Sus Scrofa database was chosen. In order to seek the possibility of the associations between DE genes, the combined score of 0.15 was chosen. The network of predicted associations for all of the DE genes encoded proteins are shown in Additional file 5. Some molecules are the key molecules that link to other proteins according to the STRING analysis. However, many proteins do not link to others, indicating that their functions are unrelated or unknown. As shown in Figure 2A, a total of $12 \mathrm{DE}$ genes encoded proteins are associated with IL- $1 \beta$ according to the textmining evidence, and they form the IL-1 $\beta$ network. Furthermore, the CD14 and SOD2 are associated with IL-1 $\beta$ according to the co-expression evidence. Two of phagocytosis-related genes $(c d 14, f c g r 2 \beta)$ are associated with a total of $11 \mathrm{DE}$ genes encoded proteins (Figure $2 \mathrm{~B}$ ) according to the textmining evidence, and they form the phagocytosis network. Furthermore, the IL-1 $\beta$, FGL-2, CCL2 and FCGR2 $\beta$ are associated with CD14 according to the coexpression evidence.

\section{Identification of novel infection-related DE genes}

In order to identify novel candidates for disease-related DE genes, we evaluated the DE genes that were not highlighted in the KEGG or STRING analysis. Although the s100a4, s100a6 and coronin $1 a$ were not highlighted in the KEGG or STRING analysis, they were found to play roles in the immune response [23-34]. These observations suggest that the three genes may be novel candidates for disease-related DE genes.

Among the three genes, coronin $1 a$ has not been identified in pigs before. So we cloned and sequenced the porcine coronin $1 a$ gene according to description of Liu et al [35] and the sequence was submitted to the GenBank [GenBank: JN092377]. The full-length cDNA of porcine coronin 1 a contains $1386 \mathrm{bp}$ and 461 amino acid residues. Multiple sequence alignment with the 
Table 2 The DE genes associated with immune and inflammatory response in PAM after $H$. parasuis serovar 5 infection 6 days

\begin{tabular}{|c|c|c|c|c|c|}
\hline Functional classification & Gene Description & GenBank ID & $\begin{array}{c}\text { Fold } \\
\text { Change }\end{array}$ & Score (d) & $q$-value (\%) \\
\hline \multicolumn{6}{|l|}{$\begin{array}{l}\text { Immune and inflammatory } \\
\text { response }\end{array}$} \\
\hline & Fc fragment of IgG, low affinity IIb, receptor & NM_001033013.1 & 24.5846355 & 7.08397559608837 & 0 \\
\hline & Chemokine (C-C motif) ligand 2 & NM_214214.1 & 10.66938955 & 3.61587781284878 & 0.542032509 \\
\hline & Chemokine (C-C motif) receptor 5 & NM_001001618 & 9.336150413 & 6.3078994808823 & 0 \\
\hline & Chemokine (C-C motif) ligand 3-like 1 & NM_001009579.1 & 3.984785551 & 5.9277826808052 & 0 \\
\hline & Chemokine ligand 4 & NM_213779.1 & 3.27736509 & 4.8388236052463 & 0 \\
\hline & S100 calcium-binding protein A14 & AK240199 & 1.774087863 & 2.21222644012883 & 3.76387374 \\
\hline & S100 calcium-binding protein A6 & NM_001044557.1 & 2.496131662 & 2.1433599692719 & 4.658259579 \\
\hline & S100 calcium-binding protein A4 & XM_001929560.1 & 5.120172033 & 9.15364933294775 & 0 \\
\hline & $C D 247$ & AK239043.1 & 2.33533278 & 3.72704398328664 & 0.542032509 \\
\hline & CD14 molecule & NM_001097445.2 & 2.798496395 & 3.06576353306702 & 0.993281247 \\
\hline & $\begin{array}{c}\text { low density lipoprotein receptor related } \\
\text { protein } 11\end{array}$ & NM_032832.5 & 6.960187733 & 5.253204788 & 0 \\
\hline & chemokine (C-X-C motif) receptor 7 & XM_003133759.1 & 6.215116279 & 6.960762567 & 0 \\
\hline & ring finger protein 128 & NM_001076071.1 & 14.61041884 & 4.192025143 & 0 \\
\hline & $\begin{array}{l}\text { transforming growth factor, beta-induced, } \\
\qquad 8 \mathrm{kDa}\end{array}$ & XM_001111447.2 & 4.110924648 & 4.879669438 & 0 \\
\hline & lymphotoxin beta & AK234043.1 & 2.971296231 & 3.522685959 & 0.542032509 \\
\hline & interleukin 1 beta & NM_214055.1 & 2.897736981 & 2.601362002 & 2.021414468 \\
\hline & chemokine (C X C motif) ligand 14 & XM_003123950.1 & 8.306998658 & 3.343782966 & 0.790729777 \\
\hline & granzyme $\mathrm{H}$ & NM_001143693.1 & 4.809267807 & 3.458161153 & 0.790729777 \\
\hline & protein kinase $C$ theta & NM_001001640.1 & 3.106802289 & 3.332538502 & 0.790729777 \\
\hline & $\begin{array}{l}\text { superoxide dismutase 2, mitochondrial } \\
\text { (SOD2) }\end{array}$ & NM_214127.2 & 2.647298815 & 2.852910519 & 1.387404311 \\
\hline & caveolin 2 & NM_001123091.1 & 5.305246137 & 4.935617987 & 0 \\
\hline & CD2 molecule & NM_213776.1 & 4.680082645 & 4.576351885 & 0 \\
\hline
\end{tabular}

identified coronin $1 a$ of cattle, human, mouse, rat and the predicted coronin $1 a$ of other species showed that the nucleotide sequence of the poCORONIN 1A ORF is 93.58\%, 93.58\%, 92.42\%, 92.35\%, 92.28\%, 91.70\%, 87.81\% and $86.87 \%$ identical to that of panda, cattle, human, chimpanzee, northern white-cheeked gibbon, common marmoset, mouse and rat coronin $1 a$, respectively. At the amino acid level, the corresponding identities were 96.96\%, 97.61\%, 95.66\%, 95.66\%, 95.88\%, 96.10\%, 93.71\% and $92.84 \%$, respectively. To define the molecular evolutionary history of poCORONIN 1A, protein sequences from 9 vertebrates were obtained to construct a phylogenetic tree. Phylogenetic analysis showed that poCORONIN 1A belongs to the group containing the Bos taurus sequence (Additional file 6). Structural analysis with the ExPASy server http://expasy.org/ indicated that the poCORONIN 1A contains putative domains of TrpAsp (WD) repeats signature, Trp-Asp (WD) repeats profile and Trp-Asp (WD) repeats circular profile at the $\mathrm{N}$-terminus (Additional file 7).
Expression analyses of S100A4, S100A6 in PK15 cells stimulated with LPS and Poly (I:C)

In order to investigate the expression patterns of s100a4 and s100a6 under general conditions that mimic bacterial and viral infection, the immunostimulation assay was carried out in PK-15 cells by using the LPS and Poly (I: C) as the stimulators.

Overnight cultures of PK-15 cells were treated with 1 $\mu \mathrm{g} / \mathrm{ml}$ LPS or $10 \mu \mathrm{g} / \mathrm{ml}$ Poly (I:C) for $0,2,6,12,24$ and 48 h. LPS and Poly (I:C) stimulation did not induce expression of porcine s100a4 until $48 \mathrm{~h}$ (Figure 3A, C). LPS stimulation induced expression of s100a6 at $2 \mathrm{~h}$ and $12 \mathrm{~h}$, after which $s 100 a 6$ expression dropped and plateaued for 24-48 h (Figure 3B). After Poly (I:C) stimulation, the expression of $s 100 a 6$ reached the peak at $12 \mathrm{~h}$, after which s100a6 expression dropped at $24 \mathrm{~h}$, and the up-regulation of s100a6 was again observed at $48 \mathrm{~h}$ (Figure 3D). These observations indicate that both LPS and Poly (I:C) can induce the expression of porcine s100a4 and s100a6 in vitro. 
Table 3 Validation of microarray results by qPCR

\begin{tabular}{|c|c|c|c|c|c|c|}
\hline Gene & Accession & Primers & $\begin{array}{l}\text { Microarray } \\
\text { fold change }\end{array}$ & $\begin{array}{l}\text { qPCR fold } \\
\text { change }\end{array}$ & $\begin{array}{l}p- \\
\text { value }\end{array}$ & $\begin{array}{l}\text { Product } \\
\text { size }\end{array}$ \\
\hline \multirow[t]{2}{*}{ CD14 molecule ${ }^{a}$} & NM_213973.1 & $\begin{array}{l}\text { F: } \\
\text { GCAGAGGCTTTGAGGACCTTATC }\end{array}$ & 2.798496395 & 3.835 & 0.0001 & $154 \mathrm{bp}$ \\
\hline & & R:GCTGCGGATGCGTGAAGTT & & & & \\
\hline \multirow[t]{2}{*}{ CD3e molecule, epsilon (CD3-TCR complex) ${ }^{a}$} & NM_214227.1 & F:ACCTCTTAGTTCCTCCCTITG & 5.671628855 & 4.619 & 0.005 & $137 \mathrm{bp}$ \\
\hline & & R:TGCCAGCATTTACCCAGTC & & & & \\
\hline \multirow[t]{2}{*}{ heat shock protein $70.2^{b}$} & NM_213766.1 & F:AGGCGGAGAAGTACAAAGCG & 3.374059696 & 5.775 & 0.007 & $257 \mathrm{bp}$ \\
\hline & & R:GATGGGGTTACACACCTGCTC & & & & \\
\hline \multirow[t]{2}{*}{ TIMP metallopeptidase inhibitor $1^{b}$} & NM_213857.1 & F:CGCCTCGTACCAGCGTTAT & 8.614065715 & 11.357 & 0.008 & $127 \mathrm{bp}$ \\
\hline & & R:GTGGAAGTATCCGCAGACGC & & & & \\
\hline \multirow{2}{*}{$\begin{array}{l}\text { superoxide dismutase 2, mitochondrial } \\
(\text { (SOD2) })^{b}\end{array}$} & NM_214127.2 & F:TCTGGACAAATCTGAGCCCT & 2.647298815 & 2.1687 & 0.003 & $119 \mathrm{bp}$ \\
\hline & & R:GACGGATACAGCGGTCAACTT & & & & \\
\hline \multirow[t]{2}{*}{ S100A4 } & XM_001929560.1 & F:GTCCACCTTCCACAAGTA & 5.120172033 & 5.4957 & 0.006 & $152 \mathrm{bp}$ \\
\hline & & R:TGTCCAAGTTGCTCATCA & & & & \\
\hline \multirow[t]{2}{*}{ S100A6 } & NM_001044557.1 & F:AAGGCTGATGGAAGACTT & 3.082743701 & 5.5237 & 0.016 & $105 \mathrm{bp}$ \\
\hline & & R:TTGAGGGCTTCATTGTAGA & & & & \\
\hline \multirow[t]{2}{*}{ Caveolin 1} & NM_214438.2 & $\mathrm{F}:$ СTTCACCACCTTCACTGT & 4.301157871 & 2.319 & 0.041 & $184 \mathrm{bp}$ \\
\hline & & R:GGAATAGACACGGCTGAT & & & & \\
\hline \multirow[t]{2}{*}{ Caveolin 2} & NM_001123091.1 & F:GCAGACAATATGGAAGAGTG & 5.305246137 & 3.327 & 0.011 & $85 \mathrm{bp}$ \\
\hline & & R:CAGGCTGACAGAAGAGAA & & & & \\
\hline \multirow[t]{2}{*}{ coronin, actinbinding protein, $1 A(C O R O 1 A)$} & BT025463.1 & $\begin{array}{l}\text { F: } \\
\text { GTGGACTGGAGCCGAGATGGA }\end{array}$ & 6.065784814 & 5.7667 & 0.0001 & $200 \mathrm{bp}$ \\
\hline & & R:GCCACCTGCCGCTCACTC & & & & \\
\hline \multirow{2}{*}{$\begin{array}{l}\text { protein phosphatase1, regulatory (inhibitor) } \\
\text { subunit } 13 \text { like (PPP1R13L) }\end{array}$} & XM_002801296.1 & F:CACCAGAGCAGCCGCAGAG & 0.506516661 & 0.2116 & 0.0001 & $107 \mathrm{bp}$ \\
\hline & & $\begin{array}{l}\text { R: } \\
\text { GTCCAGGAGGAGCACCAGAGG }\end{array}$ & & & & \\
\hline
\end{tabular}

a: Primers from reference 87

b: Primers from reference 16

In vivo expression of s100a4 and s100a6 in pigs with systemic infection of $\boldsymbol{H}$. parasuis

In order to understand the expression of the s100a4 and $s 100 a 6$ in pigs with systemic infection of $H$. parasuis, the different tissues obtained from the $H$. parasuis infected pigs and the controls were selected for the qPCR analysis. Our qPCR examination demonstrated that the increasing expression of s100a4 was observed in the lungs, spleen and lymph nodes of pigs infected with $H$. parasuis for 6 days (Figure 4A). The expression of s100a6 in the lungs, spleen and lymph nodes had the same expression tendencies (Figure 4B). However, in brain and heart of $H$. parasuis infected pigs, the expression of s100a4 and s100a6 did not show significant changes compared to the controls.

\section{Discussion}

During infection, $H$. parasuis has to reach the lung and survive the host pulmonary defenses before invading the blood stream [13]. In the lung, bacteria have to confront alveolar macrophages, whose main roles include: ingestion of bacteria by phagocytosis, destruction of bacteria within phagolysosomes and recruitment of inflammatory cells to the site of infection via chemokines and acutephase proteins [36].

Phagocytosis is a cytoskeleton-dependent process of engulfment of large particles, and macrophages could present a restricted number of phagocytic receptors that induce rearrangements in the actin cytoskeleton that lead to the internalization of the particle [36]. Phagocytosis is a key mechanism used by macrophages to control virulent Pasteurellaceae, such as Pasteurella multocida, Haemophilus parasuis, Haemophilus influenzae, Actinobacillus pleuropneumoniae [13,37-40]. In this study, the $c d 14$ [41-44], hmox 1 [45], fcgr $2 \beta$ [46] and abca1 [47] genes, which were identified as DE genes, were also found to be involved in the phagocytosis. Meanwhile, the STRING analysis indicated that many DE gene encoded proteins could interact with CD14 and FCGR2 $\beta$ molecules, suggesting that PAMs may upregulate these genes to facilitate the phagocytosis of $H$. parasuis or other cells to play their immunological roles.

One of the important mechanisms used by macrophage to play its immunological functions is to kill 


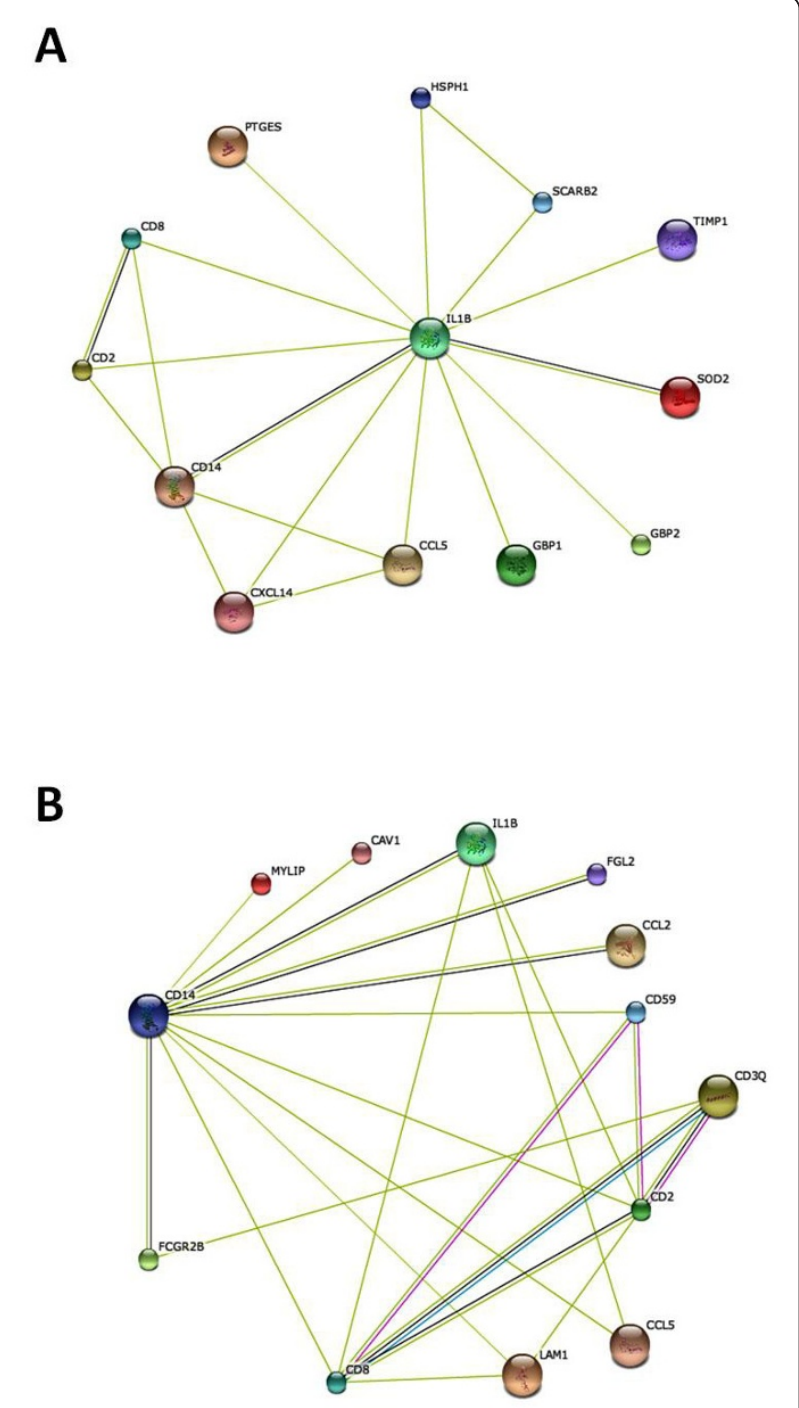

Figure 2 STRING analysis of the relationship between DE genes. The DE genes were analyzed using the Sus Scrofa STRING database. The network nodes represent the proteins encoded by the DE genes. Seven different colored link a number of nodes and represent seven types of evidence used in predicting associations. A red line indicates the presence of fusion evidence; a green line represents neighborhood evidence, a blue line represents coocurrence evidence; a purple line represents experimental evidence; a yellow line represents textmining evidence; a light blue line represents database evidence and a black line represents coexpression evidence. A: The network of DE genes related to IL-1 $\beta$. $B$ : The network of DE genes related to phagocytosis.

bacteria by the activation and recruitment of antibacterial effectors to the phagolysosome [36]. The fusion of phagosomes with lysosomes results in the formation of phagolysosomes $[11,36]$. In our study, we found two DE genes that were related to the formation of phagolysosome, that is, smpd1 [48] and coronin 1a [29-31]. Interestingly, many groups have reported that the CORONIN
1A could prevent lysosomal delivery and allow the bacteria to survive intracellularly [30,32-34]. In the course of infection, $H$. parasuis has to survive from the host pulmonary defense, such as alveolar macrophages, to produce disease. In this way, the up-regulation of coronin 1 a gene may facilitate the $H$. parasuis in producing the disease.

Interleukin-1 beta (IL-1 $\beta$ ) is an important inflammation-associated gene that is up-regulated in many microarray experiments $[11,14,16,49]$. Interestingly, Wilkinson et al reported that an increase in IL-1 $\beta$ gene expression is observed in $H$. parasuis-infected lungs [50]. In our study, IL-1 $\beta$ was also up-regulated in $H$. parasuisinfected PAMs. Unsurprisingly, STRING analysis also revealed that many molecules encoded by up-regulated genes interact with IL- $1 \beta$ and form the IL- $1 \beta$ network. Meanwhile, the pathway analysis indicated that IL-1 $\beta$ is in some pathways, such as cytokine-cytokine receptor interaction ( $p=2.18 \mathrm{E}-10)$, MAPK signaling pathway ( $p$ $=7.63 \mathrm{E}-04)$, and toll-like receptor signaling pathway ( $p$ $=1.93 \mathrm{E}-05)$. CCL5/RANTES plays an important role in regulating the movements of inflammatory cells to the infection sites [51,52]. Many viruses, such as Japanese encephalitis virus (JEV) [53], respiratory syncytial virus (RSV) [54], influenza virus A [55] and porcine reproductive and respiratory syndrome virus (PRRSV) [51] have been shown to induce CCL5. In addition, some papers have reported that the CCL5 could be induced in macrophages by bacterial infections, such as Salmonella typhimurium infection, Streptococcus pyogenes infection and Lactobacillus rhamnosus infection $[56,57]$. Interestingly, in our study, the up-regulation of CCL5 was observed in $H$. parasuis-infected PAMs, which suggested that CCL5 plays a role in the host response against $H$. parasuis infection. Thus, during the $H$. parasuis infection, the PAMs mount a powerful inflammatory response in an effort to clear this pathogen. Alternatively, the influx of inflammatory cells to the site of infection may provide additional host cells for $H$. parasuis infection. However, sustained or excessive production of inflammatory cytokines can have damaging consequences. To counterbalance inflammatory cytokines, anti-inflammatory cytokines are produced. Antiinflammatory cytokines include interleukin 10 (IL-10), transforming growth factor $\beta$ (TGF- $\beta$ ), and IL-1 receptor antagonist (IL-1RA) $[11,58,59]$. Wilkinson et al reported that the IL-1 $\beta$ and its antagonist, IL-1RA are both more highly expressed in "susceptible" animals challenged with $H$. parasuis [50]. In our study, TGF- $\beta$, an anti-inflammatory cytokine, was increased in $H$. parasuis infection group. During $H$. parasuis infection, anti-inflammatory signals may decrease the potentially damaging effects of proinflammatory cytokines on host tissue. 
A

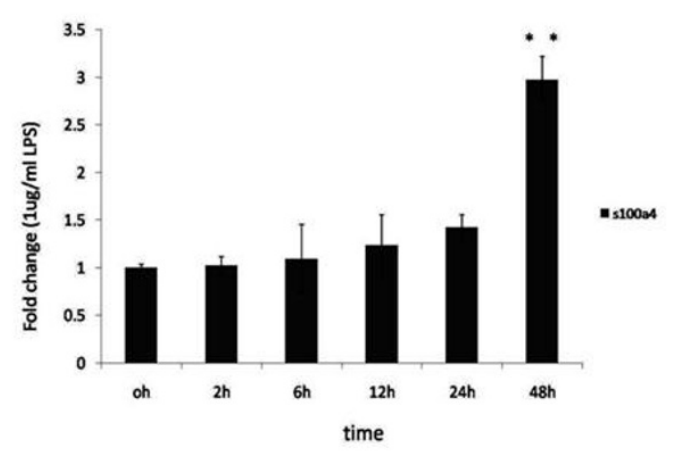

C

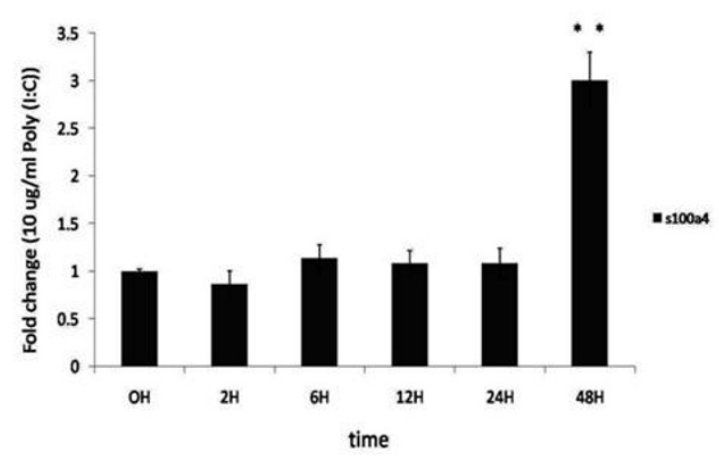

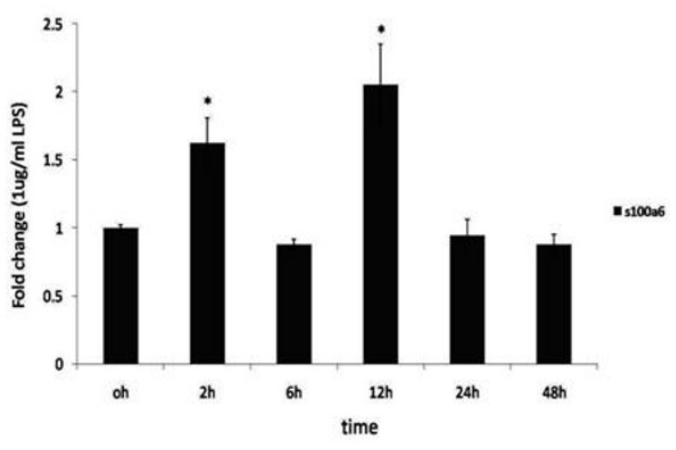

D

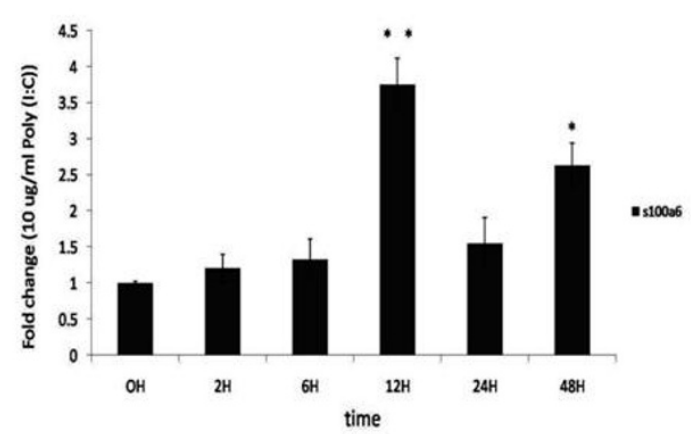

Figure 3 Kinetic immune stimuli analyses challenged by LPS and Poly (I:C) in PK-15 cells. A, B: LPS-induced expression of porcine s100a4 and $5100 a 6$ in PK-15 cells respectively. PK-15 cells were cultured with $1 \mu \mathrm{g} / \mathrm{mL}$ LPS for 48 h. C, D: Poly (l:C) induced expression of porcine s100a4 and s100a6 in PK-15 cells respectively. PK-15 cells were cultured with $10 \mu \mathrm{g} / \mathrm{mL}$ Poly (l:C) for $48 \mathrm{~h}$. Relative expression of s100a4 and s100a6 were detected by qPCR and normalized to the expression of GAPDH. The fold increase is expressed as the mean of three replicates with SEM by comparison with the control $(0 \mathrm{~h})$. QPCR was performed using primers described in Table 3. The significance of difference for the expression compared to the untreated control $(0 \mathrm{~h})$ was calculated using two-directional paired Student's T-test. ${ }^{*} p \leq 0.01 ;{ }^{*} p \leq 0.05$.

Macrophage also effectively controls bacterial infection by producing of reactive species such as oxygen species and nitric oxide (NO). Sustained production of NO endows macrophages with cytostatic or cytotoxic activity against viruses, bacteria, fungi, protozoa, helminths and tumor cells. Unsurprisingly, $H$. parasuis infection could cause up-regulated expression of a large set of genes involved in the nitric oxide production. These genes were: spr, rora, klrk1, sod 2 and $i l-1 \beta$ [60-66]. The upregulated genes related to the nitric oxide production may contribute to the PAM for confronting $H$. parasuis infection.

The DE genes that are related to phagocytosis, formation of phagolysosome, chemokines production, and nitric oxide production may help us to better understand the complicated mechanisms by which PAMs play their functions. Another highlight of our study is the new identified candidate genes that may be implicated in the pathogenesis of Glässer's disease. These genes could help to screen the potential host agents for reducing the prevalence of $H$. parasuis and further understand the molecular pathogenesis associated with H. parasuis infection in pigs. These genes are: s100a4, s100a6, caveolin 2 and ppp1r13l.

S100 A4 and S100 A6 belong to the S100 family that contained 2 EF-hand calcium-binding motifs [23,27]. Two of S100 family genes (S100 calcium-binding protein A8 and A9) are dramatically up-regulated in spleen and lung following $H$. parasuis infection [67]. Meanwhile, many other S100 family genes are up-regulated following different bacterial and viral infection $[16,18,67,68]$, suggesting that the S100 family genes play roles in the immune response to infections. In our study, the S100 calcium-binding protein A4 and A6 were up-regulated after $H$. parasuis infection when determined by microarray and qPCR. Further immunostimulation analysis indicated that the mRNA levels of S100 calcium-binding protein A4 (S100A4) and S100 calcium-binding protein A6 (S100A6) in porcine PK-15 cells increased within 48 $h$ and were sustained after administration of LPS and 


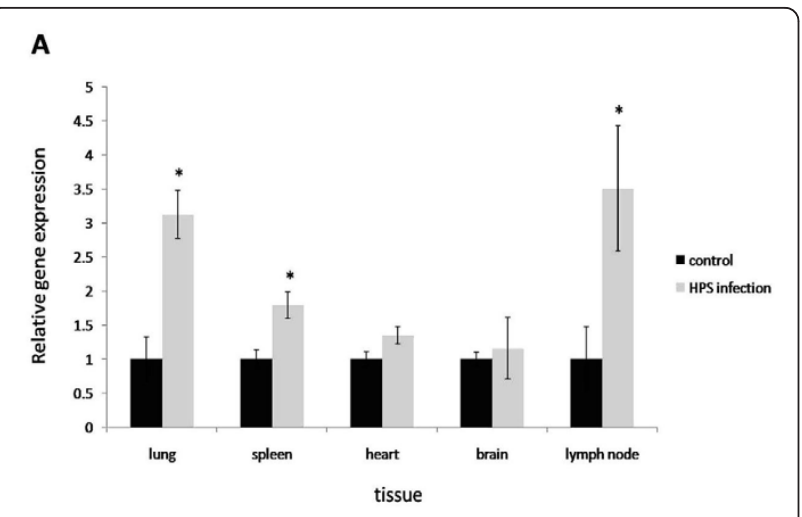

B

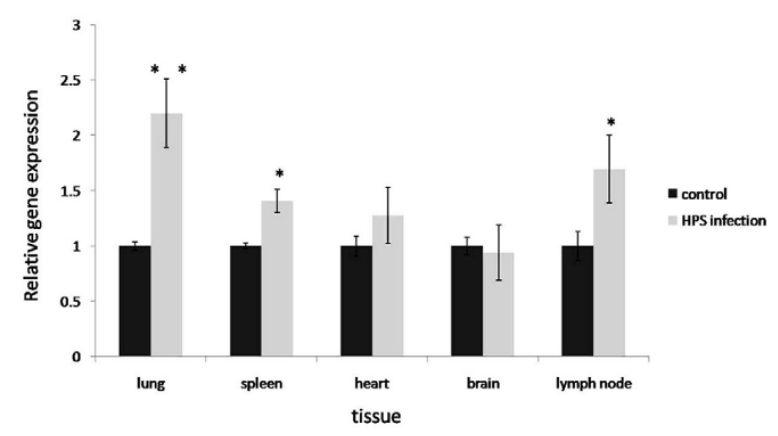

Figure 4 Quantitative expression of s100a4 and s100a6 in five tissues from pigs with Glässer's disease. A: Increased in vivo gene expression of s100a4 in lungs, spleen, lymph nodes of pigs with Glässer's disease. B: Increased in vivo gene expression of s100a6 in lungs, spleen, lymph nodes of pigs with Glässer's disease. Relative expression of s100a4 and s100a6 were detected by qPCR and normalized to the expression of GAPDH. The fold increase is expressed as the mean of three replicates with SEM by comparison with the control. The significance of difference for the expression compared to the control was calculated using two-directional paired Student's T-test. ${ }^{* *} p \leq 0.01 ;{ }^{*} p \leq 0.05$.

Poly (I:C) respectively. We also found that the s100a4 and s100a6 genes were up-regulated in lungs, spleen and lymph nodes in $H$. parasuis infected pigs. Interestingly, the kidney fibrosis [24-26,69], liver fibrosis [70,71], lung fibrosis [72-74], cardiac fibrosis [23,75,76] and peritoneal fibrosis [77] are found to be related to the expression of s100a4. Glässer's disease is characterized mainly by fibrinous polyserositis, meningitis, and arthritis. In this way, we hypothesized that the increase expression of $s 100 a 4$ may underlie fibrosis during $H$. parasuis infection in pigs. Meanwhile, some reports indicated that $5100 a 6$ plays roles in cell proliferation and signaling transduction $[27,28]$. Therefore, the s100a4 and s100a6 genes could be two novel genes related to $H$. parasuis infection.

Caveolins are the major components and protein markers of caveolae that are 50-100 $\mathrm{nm}$ invaginations of membrane. The caveolin gene family includes three members in vertebrates, caveolin-1, caveolin-2 and caveolin-3, of which caveolin 1 and caveolin 2 have been detected in mouse macrophages $[35,78]$. Caveolin 1 molecule is related to $H$. parasuis infection [35]. Caveolin 2, which localizes to the Golgi complex but redistributes to plasma membrane, caveolae and rafts when co-expressed with caveolin 1, is a potential key molecule related to the Pseudomonas infection causing pneumonia in patients with cystic fibrosis and other immunocompromising conditions $[79,80]$. In our study, the caveolin 2 gene was highly expressed in PAM isolated from the $H$. parasuis serovar 5 challenged group. Therefore, in addition to the caveolin 1 gene, the caveolin 2 gene may be a novel candidate gene related to $H$. parasuis infection.

The NF-kappa B (NF- $\kappa \mathrm{B})$ signaling pathway is important in signal transduction during the innate immune response [36]. NF- $\kappa \mathrm{B}$ signaling relies on the targeting of $\mathrm{I} \kappa \mathrm{B}$ (inhibitor of $\mathrm{NF}-\kappa \mathrm{B}$ ) subunit to the proteasome to allow NF- $\kappa \mathrm{B}$ to translocate from the cytosol to the nucleus where it activates gene transcription [81]. The PPP1R13L is mentioned as a novel inhibitor of NF- $\kappa \mathrm{B}$ [82]. In our study, microarray and qPCR analysis indicated that the mRNA of PPP1R13L was down-regulated significantly compared to control. The IPA network indicated that the PPP1R13L could directly or indirectly interacts with many molecules, such as micro RNAs, transcriptions, enzymes, and cytokines (Additional file $8)$, suggesting that ppp1r13l gene is an innate immune related gene that plays a role in PAM during $H$. parasuis infection. The detailed mechanism of ppp $1 r 13 l$ gene in NF- $\kappa \mathrm{B}$ signaling pathway in $H$. parasuis infected PAM needs further studies.

\section{Conclusion}

This is the first study focusing on response of porcine alveolar macrophages to Haemophilus parasuis by using the Affymetrix GeneChip Porcine Genome Array. Although great efforts have been made to understand the molecular basis of $H$. parasuis infection, the cellular response to $H$. parasuis infection is still largely unknown. The high-density cDNA array technology to analysis of $H$. parasuis-infected PAM could improve our understanding of the $H$. parasuis infection. Our data show that a series of genes are activated upon $H$. parasuis infection. These genes are involved in inflammatory response, immune response, microtubule polymerization, regulation of transcript and signal transduction. Particularly, some genes related to phagocytosis, formation of phagolysosome, chemokines production and nitric oxide production could contribute to explain the complicated mechanisms by which PAM played its functions. Some new identified genes may also provide 
implication on the pathogenesis of Glässer's disease caused by $H$. parasuis.

\section{Methods}

Animals for Microarray experiment and porcine alveolar macrophages isolation

All animals' tissue collection procedures were performed according to protocols approved by the Hubei Province PR China for Biological Studies Animal Care and Use Committee. Six piglets which were obtained from a commercial herd free of Glässer's disease were weaned at 27 days, shipped to the Animal Disease Center of Huazhong Agricultural University, and raised with isolation facilities. Three piglets were randomly allocated to the non infected group and three to the infected group. The three piglets were intratracheally challenged with $H$. parasuis strain 0165 (serovar 5) at a dose of $6 \times 10^{9}$ colony-forming units (CFU). The noninfected group piglets were treated similarly with identical volume of PBS served as control. All piglets were determined to the HPS-free by serum indirect haemagglutination (IHA) test before artificial bacterial challenges. Clinical signs and lesions of Glässer's disease were apparent in the challenged group at 6 days post-infection (dpi). All piglets were slaughtered at $6 \mathrm{dpi}$. Bacterial isolation, nested PCR and LAMP were performed after the piglets were killed at $6 \mathrm{dpi}$. PAMs were isolated according to Olvera's description [13]. Briefly, Bronchoalveolar lavage of the lungs was performed with $100 \mathrm{~mL}$ aliquots of sterile PBS containing gentamicin at $70 \mu \mathrm{g} / \mathrm{mL}$ (SigmaAldrich). To collect the porcine alveolar macrophages (PAM), lavage fluids were centrifuged at $230 \mathrm{~g}$ for 15 min, and then cells were washed twice with Dulbecco's Modified Eagle's Medium (DMEM) with gentamicin (50 $\mu \mathrm{g} / \mathrm{mL}$ ). PAM isolation was confirmed by detection of macrophage markers (SWC3, CD169 and SLAII) in the cells by flow cytometry.

\section{RNA preparation for Microarray experiment}

Total RNA were extracted from PAM of each group with Trizol (Invitrogen) then quantified using the NanoDrop 1000 Spectrophotometer (Thermo Fisher Scientific Inc., USA). The quality of the RNA was checked by formaldehyde denaturing gel electrophoresis in $1.2 \%$ agarose gels, which showed dispersed bands (28S and $18 \mathrm{~S}$ ) without any obvious smearing patterns that would indicate degradation.

\section{Microarray hybridization and data analyses}

Affymetrix GeneChip Porcine Genome Array, which contains 24,123 probe sets to interrogate 23,256 transcripts in pig, represents 20,201 genes, was used in microarray analysis. Hybridization, data capture and analysis were performed by CapitalBio Corporation
(Beijing, China), a service provider authorized by Affymetrix Inc. (Santa Clara, CA). Briefly, a total of $1 \mu \mathrm{g}$ RNA was used for CDNA synthesis and to produce biotin-tagged cRNA with GeneChip IVT Labeling kit (Affymetrix). A total of $15 \mu \mathrm{g}$ fragmented cRNA, with contol oligo B2 and eukaryotic hybridization controls (bioB, bioC, bioD, cre) was hybridized to each GeneChip array at $45^{\circ} \mathrm{C}$ for 16 hours (Affymetrix Gene Chip Hybridization Oven 640) according to manufacturer's instructions. After hybridization, the GeneChip arrays were washed and stained with streptavidin phycoerythrin onan (SAPE) with Affymetrix Fluidics Station 450 followed by scanning with the Affymetrix GeneChip Scanner 3000. Six microarrays were used in the experiment, corresponding to the RNAs from PAMs of three $H$. parasuis infected piglets and three controls.

The hybridization data were analyzed using GeneChip Operating Software (GCOS, version 1.4), which uses statistical criteria to generate a 'present' or 'absent' call for genes represented by each probe set on the array. The scanned images were first assessed by visual inspection and then analyzed to generate raw data files saved as CEL files using the default setting of GCOS 1.4. Microarray data were normalized using the robust multi-array average (RMA) method [83], which consists of three steps: background correction, quantile normalization (each performed at the individual probe level), and robust linear model fit using log-transformed intensities (at the probe set level). Significance Analysis of Microarrays (SAM) add-in to Microsoft Excel was used for comparisons of replicate array experiments. SAM identifies genes with statistically significant changes in expression by assimilating a set of gene-specific $t$-tests, and provides an estimate of the false discovery rate (FDR) from randomly generated data. Genes with scores higher than a threshold value or genes with FDR value lower than the threshold value were deemed potentially significant. Furthermore, fold-change analysis which calculates the ratios of geometric means of expression intensities of $H$. parasuis-infected PAMs relative to controls was performed. These ratios were reported as the up-or downfold change. In this study, genes were considered statistically significant if they had SAM $|\operatorname{Score}(d)| \geq 2[84,85]$ and exhibited a fold change $\geq 1.33$ and $\leq 0.75$. DE genes performed for hierarchical cluster (Ver.3.0) and TreeView (Ver.1.1.1) analyses. Genes with significant similarities to the transcripts in $\mathrm{nr}$ database based on BLASTX searches were selected for GO analysis, performed by MAS 3.0 software which was based on DAVID database (CapitalBio, Beijing, China) [16]. Annotation results were obtained by inputting the list of gene symbol as identifier [18]. The Pathway analysis was done using the MAS 3.0 software which was based on the Kyoto Encyclopedia of Genes and Genomes database 
(KEGG) (CapitalBio, Beijing, China). All microarray results from this study were deposited in NCBI'S Gene Expression Omnibus (GEO) database, accession numbers are: Platform, GPL 3533, Samples, GSM 747145, GSM 747146, GSM 747147, GSM, 747148, GSM 747149 , GSM 747150 with the series accession number GSE 30172.

\section{QPCR analysis}

Total RNA were extracted from the PAMs of each group with Trizol (Invitrogen) and $5 \mu \mathrm{g}$ of total RNA were used for first strand cDNA synthesis by using Superscript II cDNA amplification System (Invitrogen) following manufacturer's instructions. Real-time PCR was performed using LightCycler 480 (Roche Applied Science) and Quantitect SYBR Green PCR kit (Roche) following the companies' instructions. Briefly, PCR assay was performed under the following conditions: $95^{\circ} \mathrm{C}$ for $15 \mathrm{sec}, 55^{\circ} \mathrm{C}$ for $15 \mathrm{sec}$ and $72^{\circ} \mathrm{C}$ for $15 \mathrm{sec}$. Real-time PCR primers for each gene were indicated in Table 3. All the primers were originally designed using Primer 3 software (Rozen \& Skaletsky, 2000) or according to the published papers. Results were calculated by minus delta delta threshold cycle (-ddCt) method. Briefly, the threshold cycle $\mathrm{Ct}_{1}$ of each sample reaction were deducted with the threshold cycle $\mathrm{Ct}_{2}$ of GAPDH reaction for normalization, then deducted from the threshold cycle $\mathrm{Ct}_{3}$ of calibration control (40 Cycles in this experiment); thus, the final result was represented by the formula: $\mathrm{Ct}_{3}-\left(\mathrm{Ct}_{1}-\mathrm{Ct}_{2}\right)$.

\section{Expression of S100A4, S100A6 in PK-15 cells stimulated with LPS and Poly (I:C)}

PK-15 cells have been shown especially useful for the study of infectious disease processes in swine [86,87]. In this study, 12 groups (with three repeats in each group, $\sim 1 \times 10^{5}$ cells/samples) of PK-15 cells were grown in culture medium (DMEM) supplemented with $10 \%$ heatinactivated fetal bovine serum at $37^{\circ} \mathrm{C}$ with $5 \% \mathrm{CO}_{2}$. Adherent PK-15 cells were obtained by washing off nonadherent cells with warm culture medium and PBS twice, respectively. Adherent cells were further cultured in DMEM (control samples) or treated with $1 \mu \mathrm{g} / \mathrm{mL}$ LPS (Sigma-Aldrich, E.coli 0127:B8) or $10 \mu \mathrm{g} / \mathrm{mL}$ Poly (I:C) (Sigma-Aldrich) respectively (stimulated samples) for $0 \mathrm{~h}, 2 \mathrm{~h}, 6 \mathrm{~h}, 12 \mathrm{~h}, 24 \mathrm{~h}$ and $48 \mathrm{~h}$. Cells were harvested and total RNA were extracted as described above.

\section{DNA preparation from bacterial isolates and clinical samples}

Bacterial cultures were harvested from trypticase soy agar (TSA) using an inoculation loop and were placed into a $1.5 \mathrm{~mL}$ tube to which was added with $500 \mu \mathrm{L}$ of phosphate buffered saline (PBS). One milliliter of the fluid and $0.5 \mathrm{~g}$ of the tissue samples were respectively placed in sterile tubes containing $5 \mathrm{~mL}$ of trypticase soy broth (TSB), $5 \mu \mathrm{L}$ nicotinamide adenine dinucleotide (NAD) and $500 \mu \mathrm{L}$ sterilized fetal bovine serum and then incubated for $8 \mathrm{~h}$ at $37^{\circ} \mathrm{C}$ with agitation. Five hundred microliters of the suspension was removed to a new $1.5 \mathrm{~mL}$ tube. Tubes containing bacteria, tissue and fluid suspensions were centrifuged at $13,400 \mathrm{~g}$ for 5 min. After centrifugation, the supernatant was discarded and the remaining pellet was suspended in $200 \mu \mathrm{L}$ PBS, boiled for $10 \mathrm{~min}$. After boiling, tubes were centrifuged at $13,400 \mathrm{~g}$ for $5 \mathrm{~min}$. Fifty microliters of supernatant from each sample containing extracted DNA were mixed with $50 \mu \mathrm{L}$ of Tris-EDTA buffer and stored at $4^{\circ}$ C. This final solution was used as DNA template in nested PCR and LAMP reaction. The primers for nested PCR and LAMP were listed in Additional file 9. The procedure of bacterial isolation, nested PCR and LAMP were carried out according to description of Wang et al [6].

\section{Detection of s100a4 and s100a6 expression in different tissues}

Three pigs in $H$. parasuis infection group and control group were selected for the analysis of s100a4 and s100a6 expression in different tissues. Total RNA from 5 porcine organs (inguinal lymph node, heart, spleen, lung, brain) was isolated with RNAprep pure Tissue Kit (TianGen Biotech (Beijing) Co., Ltd). Total RNA was then quantified by NanoDrop 1000 Spectrophotometer (Thermo Fisher Scientific Inc., USA). The quality of the RNA was checked by formaldehyde denaturing gel electrophoresis in $1.2 \%$ agarose gels, which showed dispersed bands (28S and 18S) without any obvious smearing patterns that would indicate degradation. Two microgram of total RNA was used for reverse transcription polymerase chain reaction, using the TransSript First Strand cDNA Synthesis SuperMix according to the manufacturer's instructions (TianGen Biotech (Beijing) Co., Ltd). The qPCR assays were performed and analyzed as described above, with primers listed in Table 3.

\section{Data for STRING and IPA analysis}

Differentially expressed (DE) genes were analyzed using STRING http://string.embl.de, a database of known and predicted protein interaction for DE gene encoded proteins. The results were obtained by inputting the list of gene symbol as identifier (organism = sus scrofa, combined score $=0.15)$. Ppp1r13l gene was selected for network exploration using Ingenuity Pathway Analysis (Ingenuity ${ }^{\circledR}$ Systems, http://www.ingenuity.com). The data set containing gene identifier and corresponding expression value was uploaded into in the application. The identifier was mapped to its corresponding object 
in Ingenuity's Knowledge Base; Network Eligible molecules were then overlaid onto a global molecular network so that network of Network Eligible Molecules could be algorithmically generated based on their connectivity.

\section{Additional material}

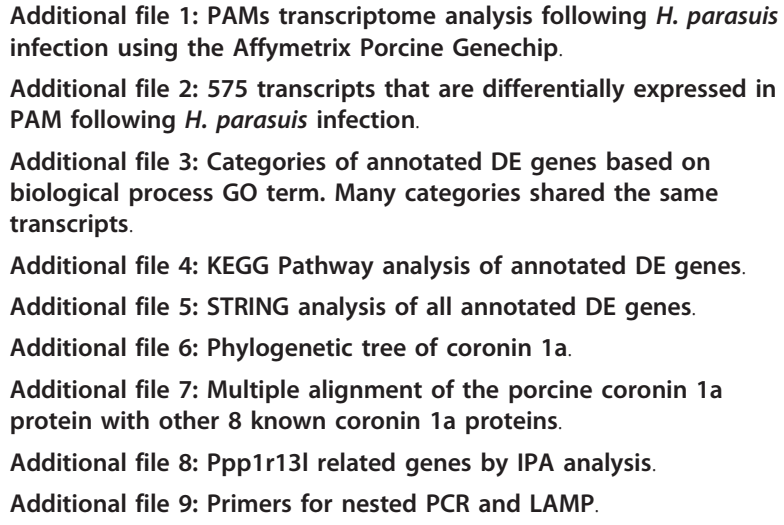

\section{Abbreviations}

H. parasuis: Haemophilus parasuis; DE: differentially expressed; FC: fold change; GO: Gene Ontology; QPCR: quantitative real-time PCR; PAM: porcine alveolar macrophages; LPS: lipopolysaccharide; Poly (l:C): polyinosinic acidpolycytidylic acid; PK-15: pig kidney-15; LAMP: loop-mediated isothermal amplification. TSA: trypticase soy agar; TSB: trypticase soy broth; NAD: nicotinamide adenine dinucleotide. MAS: Molecular Annotation System. SAM: Significance Analysis of Microarrays. FDR: false discovery rate. IPA: Ingenuity Pathway Analysis. DAVID: Database for Annotation, Visualization and Integrated Discovery. ORF: open reading frame.

\section{Acknowledgements}

We thank Dr. Liangjun Zhao (Wayne state university, USA), Xiangdong Liu, Hongbo Chen (Huazhong agricultural university, Wuhan, China) for the technical assistance.

\section{Author details}

${ }^{1}$ State key Laboratory of Agricultural Microbiology, Division of Animal Infectious Disease, Huazhong Agricultural University, Wuhan, Hubei, China.

${ }^{2}$ Merial SAS, Lyon, France. ${ }^{3}$ Keqian Animal Biological Products Co., Ltd, China.

\section{Authors' contributions}

YW and $\mathrm{CL}$ carried out all works in the lab and drafted the manuscript. YF, $X L, W L, S L, Y L, Y L$, and $C C$ participated in the animal challenge experiment and immunoassays. CC and JCA participated in the experiment design and coordination. QH conceived the study, and participated in its coordination and helped to draft the manuscript. All authors read and approved the final manuscript.

\section{Competing interests}

The authors declare that they have no competing interests.

Received: 27 July 2011 Accepted: 13 February 2012

Published: 13 February 2012

\section{References}

1. Lunney JK: Advances in swine biomedical model genomics. Int J Biol Sci 2007, 3:179-184.
2. Yang W, Pin C, Haibing G, Hui L, Qigai H: Loop mediated isothermal amplification targeting the apxIVA gene for detection of Actinobacillus pleuropneumoniae. FEMS microbiol. lett 2009, 300:83-89.

3. Oliveira S, Pijoan C: Haemophilus parasuis: new trends on diagnosis, epidemiology and control. Vet Microbiol 2004, 99:1-12.

4. Angen O, Oliver S, Ahrens P, Svensmark B, Leser TD: Development of an improved species specific PCR test for detection of Haemophilus parasuis. Vet Microbiol 2007, 119:266-276.

5. Amano H, Shibata M, Kajio N, Morozumi T: Pathologic observations of pigs intranasally inoculated with serovar 1, 4 and 5 of Haemophilus parasuis using immunoperoxidase method. J Vet Med Sci 1994, 56:639-644.

6. Yang W, Ying F, Yingyu L, Pin C, Wentao L, Shuqing L, Haoyong Z, Qigai H: Development and evaluation of loop-mediated isothermal amplification for rapid detection of Haemophilus parasuis. FEMS Microbiol. Lett 2010, 313:54-60.

7. Aderem A, Ulevitch RJ: Toll-like receptors in the induction of the innate immune response. Nature 2000, 406:782-787.

8. McGuire K, Glass EJ: The expanding role of microarrays in the investigation of macrophage responses to pathogens. Vet Immunol Immunop 2005, 105:259-275.

9. Andersson H, Hartmanova B, Ryden P, Noppa L, Naslund L, Sjostedt A: A microarray analysis of the murine macrophage response to infection with Francisella tularensis LVS. J Med Microbiol 2006, 55:1023-1033.

10. Nau GJ, Richomond JFL, Schlesinger A, Jennings EG, Lander ES, Young RA: Human macrophage activation programs induced by bacterial pathogens. P Natl Acad Sci USA 2002, 99:1503-1508.

11. Eskra L, Mathison A, Splitter G: Microarray analysis of mRNA levels from RAW2647 macrophages infected with Brucella abortus. Infect Immun 2003, 71:1125-1133.

12. Detweiler CS, Cunanan DB, Falkow S: Host microarray analysis reveals a role for the Salmonella response regulator phoP in human macrophage cell death. P Natl Acad Sci USA 2001, 98:5850-5855.

13. Olvera A, Ballester M, Norfrarias M, Sibila M, Aragon V: Differences in phagocytosis susceptibility in Haemophilus parasuis strains. Vet Res 2009, 40:24.

14. Auger E, Deslandes V, Ramjeet M, Contreras I, Nash JHE, Harel J, Gottschalk M, Olivier M, Jacques M: Host pathogen interactions of Actinobacillus pleuropneumoniae with porcine lung and tracheal epithelial cells. Infect Immun 2009, 77:1426-1441.

15. Ichikawa JK, Bangera ANMG, Geiss GK, Wout AB, Bumgarner RE, Lory S: Interaction of Pseudomonas aeruginosa with epithelial cells: identification of differentially regulated genes by expression microarray analysis of human cDNAs. P Natl Acad Sci USA 2000, 97:9659-9664.

16. Ran L, Zhang A, Chen B, Teng L, Wang Y, Chen H, Jin M: Response of swine spleen to Streptococcus suis infection revealed by transcription analysis. BMC genomics 2010, 11:556.

17. Tusher VG, Tibshirani R, Chu G: Significance analysis of microarrays applied to the ionizing radiation response. P Natl Acad Sci USA 2001, 98:5116-5121.

18. Li Y, Zhou H, Wen Z, Wu S, Huang C, Jia G, Chen H, Jin Me: Transcription analysis on response of swine lung to H1N1 swine influenza virus. BMC genomics 2011, 12:398.

19. Wang D, Pan Y, Zhao X, Zhu L, Fu B, Li Z: Genome-wide temporal-spatial gene expression profiling of drought responsiveness in rice. $B M C$ genomics 2011, 12:149.

20. Zou X, Zou L, Foldager C, Bendtsen M, Feng W, Bunger C: Different mechanisms of spinal fusion using equine bone protein extract, rhBMP2 and autograft during the process of anterior lumbar interbody fusion. Biomaterials 2009, 30:991-1004.

21. Bonetta L: Protein-protein interactions: Interactome under construction. Nature 2010, 468:851-854.

22. Von Mering C, Lars J, Jensen, Berend, Snel, Sean D, Hooper, Markus, Krupp, Mathilide, Foglierini , Nelly, Jouffre, Martijin A, Huynen, Peer, Bork : STRING: known and predicted protein Cprotein associations, integrated and transferred across organisms. Nucleic Acids Res 2005, 33:433-437.

23. Schneider M, Kostin S, Strom C, Aplin M, Lyngbak S, Theilade J, Grigorian M, Andersen CB, Lukanidin E, Hansen JL, Sheikh SP: S100A4 is upregulated in injured myocardium and promotes growth and survival of cardiac myocytes. Cardiovasc Res 2007, 75:40-50. 
24. Iwano M, Plieth D, Danoff TM, Xue C, Okada H, Neilson EG: Evidence that fibroblasts derive from epithelium during tissue fibrosis. J Clin Invest 2002, 110:341-350

25. Nishitani $Y$, Iwano $M$, Yanaguchi $Y$, Nakatani $K$, Akai $Y$, Nishino $T$, Shiiki $H$ Kanauchi M, Saito $Y$, Neilson EG: Fibroblast-specific protein 1 is a specific prognostic marker for renal survival in patients with IgAN1. Kidney Int 2005, 68:1078-1085.

26. Rivard CJ, Brown LM, Almeida NE, Maunsbach AB, Pihakashi-Maunsach K, Andres-Hernando, Capasso JM, Berl T: Expression of the calcium-binding protein S100A4 is markedly up-regulated by osmotic stress and is involved in the renal osmoadaptive response. J Biol Chem 2007, 282:6644-6652.

27. Breen EC, Tang K: Calcyclin (S100A6) regulates pulmonary fibroblast proliferation, morphology, and cytoskeletal organization in vitro. J Cell Biochem 2003, 88:848-854.

28. Slomnicki LP, Nawrot B, Lesniak W: S100A6 binds p53 and affects its activity. Int J Biochem Cell B 2009, 41:784-790.

29. Suzuki K, Nishihata J, Arai Y, Honma N, Yamamoto K, Irimura T, Toyoshima S: Molecular cloning of a novel actin-binding protein, p57, with a WD repeat and a leucine zipper motif. FEBS lett 1995, 364:283-288.

30. Ferrari $G$, Langen $H$, Naito M, Pieters J: A coat protein on phagosomes involved in the intracellular survival of mycobacteria. Cell 1999, 97:435-447.

31. De Hostos EL: The coronin family of actin-associated proteins. Trends Cell Biol 1999, 9:345-350.

32. Gatfield J, Albrecht I, Zanolari B, Steinmetz MO, Pieters J: Association of the leukocyte plasma membrane with the actin cytoskeleton through coiled coil-mediated trimeric coronin 1 molecules. Mol Biol Cell 2005, 16:2786-2798.

33. Gatfield J, Pieters J: Essential role for cholesterol in entry of mycobacteria into macrophages. Science 2000, 288:1647-1651.

34. Tanigawa K, Suzuki K, Kimura H, Takeshita F, Wu H, Akama T, Kawashima A, Ishii N: Tryptophan aspartate-containing coat protein (CORO1A) suppresses Toll-like receptor signalling in Mycobacterium leprae infection. Clin Exp Immunol 2009, 156:495-501.

35. Liu XD, Chen HB, Tong Q, Li XY, Zhu MJ, Wu ZF, Zhou R, Zhao SH: Molecular Characterization of Caveolin-1 in Pigs Infected with Haemophilus parasuis. J Immunol 2011, 186:3031-3046.

36. Rosenberger CM, Finlay BB: Phagocyte sabotage: disruption of macrophage signalling by bacterial pathogens. Nat Rev Mol Cell Bio 2003, 4:385-396.

37. Harper M, Boyce JD, Adler B: Pasteurella multocida pathogenesis: 125 years after Pasteur. FEMS microbiol. lett 2006, 265:1-10.

38. Inzana TJ: Capsules and virulence in the HAP group of bacteria. Can J Vet Res 1990, 54(Suppl):S22-27

39. Inzana T, Ma J, Workman T, Gogolewski RP, Anderson P: Virulence properties and protective efficacy of the capsular polymer of Haemophilus (Actinobacillus) pleuropneumoniae serotype 5. Infect Immun 1988, 56:1880-1889.

40. Noel GJ, Hoiseth SK, Edelson PJ: Type b capsule inhibits ingestion of Haemophilus influenzae by murine macrophages: studies with isogenic encapsulated and unencapsulated strains. J Infect Dis 1992, 166:178-182

41. Jiang Z, Georgel P, Du X, Shamel L, Sovath S, Mudd S, Huber M, Kalis C, Keck S, Galanos C: CD14 is required for MyD88-independent LPS signaling. Nature immunology 2005, 6:565-570.

42. Schiff DE, Kline L, Soldau K, Lee JD, Pugin J, Tobias PS, Ulevitch RJ: Phagocytosis of gram-negative bacteria by a unique CD14-dependent mechanism. J Leukoc Biol 1997, 62:786-794.

43. Schlegel RA, Krahling S, Callahan MK, Williamson P: CD14 is a component of multiple recognition systems used by macrophages to phagocytose apoptotic lymphocytes. Cell death and differ 1999, 6:583-592.

44. Wright SD, Ramos RA, Tobias PS, Ulevitch RJ, Mathison JC: CD14, a receptor for complexes of lipopolysaccharide (LPS) and LPS binding protein. Science 1990, 249:1431-1433.

45. Zhao C, Zhang H, Wong WC, Sem X, Han H, Ong SM, Tan YC, Yeap WH, Gan CS, Ng KQ: Identification of novel functional differences in monocyte subsets using proteomic and transcriptomic methods. $J$ Proteome Res 2009, 8:4028-4038.

46. Bliska JB, Black DS: Inhibition of the Fc receptor-mediated oxidative burst in macrophages by the Yersinia pseudotuberculosis tyrosine phosphatase. Infect Immun 1995, 63:681-685.
47. Hamon Y, Chambenoit O, Luciani M, Toti F, Chaslin S, Freyssinet J, Devaux PF, McNeish J, Marguet D: ABC1 promotes engulfment of apoptotic cells and transbilayer redistribution of phosphatidylserine. Nat Cell Biol 2000, 2:399-406.

48. Uterm hlen O, Herz J, Schramm M, Kr nke M, et al: Fusogenicity of membranes: the impact of acid sphingomyelinase on innate immune responses. Immunobiology 2008, 213:307-314

49. Gladue DP, Zhu J, Holinka LG, Sainz IF, Carrillo C, Prarat MV, O'Donnell V, Borca MV: Patterns of gene expression in swine macrophages infected with classical swine fever virus detected by microarray. Virus Res 2010, 151:10-18.

50. Wilkinson JM, Sargent CA, Pantoja LG, Tucher AW: Gene expression profiling in the lungs of pigs with different susceptibilities to Glässer's disease. BMC genomics 2010, 11:455.

51. Wang YW, Luo R, Fang L, Wang D, Bi J, Chen H, Xiao S: Porcine reproductive and respiratory syndrome virus (PRRSV) infection activates chemokine RANTES in MARC-145 cells. Mol Immunol 2010, 48:586-591.

52. Zlotnik A, Yoshie O: Chemokines: A New Classification Review System and Their Role in Immunity. Immunity 2000, 12:121-127.

53. Chen CJ, Chen JH, Chen SY, Liao SL, Raung SL: Upregulation of RANTES gene expression in neuroglia by Japanese encephalitis virus infection. $J$ Virol 2004, 78:12107-12119.

54. Casola A, Garofalo RP, Haeberle H, Elliott TF, Lin R, Jamaluddin M, Brasier AR: Multiple cis regulatory elements control RANTES promoter activity in alveolar epithelial cells infected with respiratory syncytial virus. J Virol 2001, 75:6428-6439.

55. Kujime K, Hashimoto S, Gon Y, Shimizu K, Horie T: p38 mitogen-activated protein kinase and c-jun-NH2-terminal kinase regulate RANTES production by influenza virus-infected human bronchial epithelial cells. $J$ Immunol 2000, 164:3222-3228.

56. Veckman V, Miettinen M, Matikainen S, Lande R, Giacomini E, Coccia M, Julkunen I: Lactobacilli and streptococci induce inflammatory chemokine production in human macrophages that stimulates Th1 cell chemotaxis. J Leukocyte Biol 2003, 74:395-402.

57. Pietilä TE, Veckman V, Kyllonen P, Lahteenmaki K, Korhonen TK, Julknen I: Activation, cytokine production, and intracellular survival of bacteria in Salmonella-infected human monocyte-derived macrophages and dendritic cells. J Leukocyte Biol 2005, 78:909-920.

58. Hamilton TA, Ohmori Y, Tebo JM, Kishore R: Regulation of macrophage gene expression by pro-and anti-inflammatory cytokines. Pathobiology 2000, 67:241-244.

59. Opal SM, Depalo VA: Anti-Inflammatory Cytokines. Chest 2000, 117:1162-1172

60. Franscini N, Bachli EB, Blau N, Fischler M, Walter R, Schlaffner A, Schoedon G: Functional tetrahydrobiopterin synthesis in human platelets. Circulation 2004, 110:186-192.

61. Ikeda M, Matsui K, Ishihara Y, Morita I, Murota S, Yuasa T, Miyatake T: Cerebellar nitric oxide synthase, cGMP and motor function in two lines of cerebellar mutant mice, Staggerer and Wriggle Mouse Sagami. Neurosci lett 1994, 168:65-68.

62. Diefenbach A, Hsia JK, Hsiung MYB, Raulet DH: A novel ligand for the NKG2D receptor activates NK cells and macrophages and induces tumor immunity. Eur J Immunol 2003, 33:381-391.

63. Wu Z, Qiu L: Effect of nitric oxide on iron-mediated cytotoxicity in primary cultured renal proximal tubules. Cell Biochem Funct 2001, 19:237-247.

64. Alderton WK, Cooper CE, Knowles RG: Nitric oxide synthases: structure, function and inhibition. Biochem J 2001, 357:593-615.

65. Bakalian A, Kopmels B, Messer A, Fradelizi D, Delhaye-Bouchaud N, Wollman E, Mariani J: Peripheral macrophage abnormalities in mutant mice with spinocerebellar degeneration. Res Immunol 1992, 143:129-139.

66. Jamieson AM, Diefenbach A, McMahon CW, Xiong N, Carlyle JR, Raulet DH: The role of the NKG2D immunoreceptor in immune cell activation and natural killing. Immunity 2002, 17:19-29.

67. Chen H, Lunney JK, Cheng L, Li X, Cao J, Zhu M, Zhao : S. Porcine S100A8 and S100A9: molecular characterizations and crucial functions in response to Haemophilus parasuis infection. Dev Comp Immunol 35:490-500.

68. Foell D, Frosch M, Sorg C, Roth J: Phagocyte-specific calcium-binding S100 proteins as clinical laboratory markers of inflammation. Clinica Chim Acta 2004, 344:37-51 
69. Xu Y, Wan J, Jiang D, Wu X: BMP-7 counteracts TGF-beta1-induced epithelial-to-mesenchymal transition in human renal proximal tubular epithelial cells. J Nephrol 2009, 22:403-410.

70. Zeisberg M, Yang C, Martino M, Duncan M, Rieder F, Tanjore H, Kalluri R Fibroblasts derive from hepatocytes in liver fibrosis via epithelial to mesenchymal transition. J Biol Chem 2007, 282:23337-23347.

71. Robertson H, Kirby JA, Yip WW, Jones DE, Burt AD: Biliary epithelialmesenchymal transition in posttransplantation recurrence of primary biliary cirrhosis. Hepatology 2007, 45:977-981.

72. Greenway S, van Suylen RJ, Du Marchie Sarvaas G, Kwan E: S100A4/Mts1 produces murine pulmonary artery changes resembling plexogenic arteriopathy and is increased in human plexogenic arteriopathy. Am J Pathol 2004, 164:253-262.

73. Kwapiszewska G, Wilhelm J, Wolff S, Laumanns I, Koenig IR, Ziegler A, Seeger W, Bohle RM, Weissmann N, Fink L: Expression profiling of lasermicrodissected intrapulmonary arteries in hypoxia-induced pulmonary hypertension. Respir Res 2005, 6:109.

74. Lawson WE, Polosukhin W, Zoia O, Stathopoulos GT, Han W, Plieth D, Loyd JE, Neilson EG, Blackwell TS: Characterization of fibroblast-specific protein 1 in pulmonary fibrosis. Am J Respir Crit Care Med 2005, 171:899-907.

75. Inamoto S, Murao S, Yokoyama M, Kitazawa S, Maeda S: Isoproterenolinduced myocardial injury resulting in altered S100A4 and S100A11 protein expression in the rat. Pathol Int 2000, 50:480-485.

76. Zeisberg EM, Tarnavski O, Zeisberg M, Dorfman AL, McMullen JR, Gustafsson E, Chandraker A, Yuan X, Pu WT, Roberts AB, Neilson EG, Sayegh MH, Izumo S, Kalluri R: Endothelial-to-mesenchymal transition contributes to cardiac fibrosis. Nat Med 2007, 13:952-961.

77. Okada H, Inoue T, Kanno Y, Kobayashi T, Watanabe Y, Ban S, Neilson EG, Suzuki $\mathrm{H}$ : Selective depletion of fibroblasts preserves morphology and the functional integrity of peritoneum in transgenic mice with peritoneal fibrosing syndrome1. Kidney international 2003, 64:1722-1732.

78. Gargalovic P, Dory L: Caveolin-1 and Caveolin-2 expression in mouse macrophages. J Biol Chem 2001, 276:26164-26170.

79. Zaas DW, Duncan MJ, Li G, Wright JR, Abraham SN: Pseudomonas invasion of type I pneumocytes is dependent on the expression and phosphorylation of caveolin-2. J Biol Chem 2005, 280:4864-4872.

80. Mora R, Bonilha VL, Marmorstein A, Scherer PE, Brown D, Lisanti MP, Rodriguez-Boulan E: Caveolin-2 localizes to the golgi complex but redistributes to plasma membrane, caveolae, and rafts when coexpressed with caveolin-1. J Biol Chem 1999, 274:25708-25717.

81. Yang JP, Hori M, Sanda T, Okamoto T: Identification of a novel inhibitor of nuclear factor-kB, RelA-associated inhibitor. J Biol Chem 1999, 274:15662-15670.

82. Takada N, Sanda T, Okamoto H, Yang JP, Asamitsu K, Sarol L, Kimura G, Uranishi H, Tetsuka T, Okamoto T: RelA-associated inhibitor blocks transcription of human immunodeficiency virus type 1 by inhibiting NFkappa B and Sp1 actions. J Virol 2002, 76:8019-8030.

83. Irizarry RA, Hobbs B, Collin F, Beazer-Barclay YD, Antonellis KJ, Schert U, Speed TP: Exploration, normalization, and summaries probe level data. Biostatistics 2003, 4:249-264.

84. Kasler HG, Young BD, Mottet D, Lim HW, Collins AM, Olson EN, Verdin E: Histone deacetylase 7 regulates cell survival and TCR signaling in CD4/ CD8 double-positive thymocytes. J Immunol 2011, 186:4782-4793.

85. Wu Z, Zhang W, Lu Y, Lu C: Transcriptome profiling of zebrafish infected with Streptococcus suis. Microbial pathogenesis 2010, 48:178-187.

86. Boury BN, Stabel TJ, Kehrli JM, Taylor M: Comparison of the PK (15)-and WEHI 164 (clone 13)-based bioassays for detection of porcine tumor necrosis factor. Am J Vet Res 1997, 58:1115-1119.

87. Chen H, Li C, Fang M, Zhu M, Li X, Zhou R, Li K, Zhao S: Understanding Haemophilus parasuis infection in porcine spleen through a transcriptomics approach. BMC genomics 2009, 10:64.

doi:10.1186/1471-2164-13-68

Cite this article as: Wang et al.: Transcription analysis on response of porcine alveolar macrophages to Haemophilus parasuis. BMC Genomics 2012 13:68.

\section{Submit your next manuscript to BioMed Central and take full advantage of:}

- Convenient online submission

- Thorough peer review

- No space constraints or color figure charges

- Immediate publication on acceptance

- Inclusion in PubMed, CAS, Scopus and Google Scholar

- Research which is freely available for redistribution 